\title{
Unravelling a Proterozoic basin history through detrital zircon geochronology: The case of the Espinhaço Supergroup, Minas Gerais, Brazil
}

\author{
Farid Chemale Jr. ${ }^{\text {a,* }}$, Ivo A. Dussin ${ }^{\text {b }}$, Fernando F. Alkmim ${ }^{\text {d }}$, Maximiliano Sousa Martins ${ }^{\text {c }}$, Gláucia Queiroga ${ }^{\text {, }}$ \\ Richard Armstrong ${ }^{e}$, Marcelo N. Santos ${ }^{f}$ \\ a IG-UnB, 70904-970, Brasília-DF, Brazil

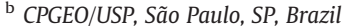 \\ ' IGC-UFMG, Campus da Pampulha, Belo Horizonte, MG, Brazil \\ d DEGEO/EM/UFOP, Morro do Cruzeiro, 35400-000, Ouro Preto, MG, Brazil \\ e RSES, ANU, Canberra, Australia \\ ${ }^{\mathrm{f}}$ PPGGEO, UFRGS, Porto Alegre-RS, Brazil
}

\section{A R T I C L E I N F O}

\section{Article history:}

Received 30 March 2011

Received in revised form 2 July 2011

Accepted 24 August 2011

Available online 24 September 2011

Handling Editor: E. Tohver

Keywords:

U-Pb zircon geochronology

Espinhaço Basin

Stenian

São Francisco Craton

Rodinia

\begin{abstract}
A B S T R A C T
New $\mathrm{U}-\mathrm{Pb}$ in situ zircon dating provides a new approach for the study of the Espinhaço Supergroup units exposed in the São Francisco Craton and Araçuaí Orogen. Located in Southern Espinhaço, Minas Gerais, the following two basins were formed in intraplate conditions: (i) the Lower Espinhaço Basin is marked by a volcano-sedimentary sequence with alluvial, fluvial and eolian deposits that were formed from $1.68 \mathrm{Ga}$ to $1.80 \mathrm{Ga}$; (ii) the overlying sequence, called the Upper Espinhaço Basin, is a rift-sag basin that presents basal diamond-bearing continental deposits (the Sopa-Brumadinho Formation) with a younger zircon peak at $1192 \mathrm{Ma}$, which is the maximum age for deposition of the upper units. The obtained U-Pb detrital zircon data of the studied units show age groupings related to the orogenic cycles of Jequie (Neoarchean) and Transamazonian (Paleoproterozoic), which are associated with the stability period from $1.8 \mathrm{Ga}$ to $0.91 \mathrm{Ga}$ in the São Franscico Craton, and record deposition during at least the three basinal cycles. The Stenian-Tonian ages of the Upper Espinhaço Basin units (906 Ma to $1192 \mathrm{Ma}$ ) suggest a direct link with the evolution of the Rodinia Supercontinent and represent a marker for Mesoproterozoic to Early Neoproterozoic evolution in the São Franscico Craton and adjacent areas.
\end{abstract}

(c) 2011 International Association for Gondwana Research. Published by Elsevier B.V. All rights reserved.

\section{Introduction}

Studies performed in Phanerozoic intracratonic (and intracontinental) basins in the last decades show that basins in this category generally correspond to successor and poly-historic depositional sites; that is, they are filled by a series of unconformity-bounded units that record distinct subsidence pulses that are distributed over relatively long time periods (Sloss, 1963 and Klein, 1995). The literature also demonstrates the importance of these basins in recording (and revealing) events (even discrete ones) that involve their hosting plates. On the other hand, the study of Archean and Proterozoic basins has produced less revealing results, mainly due to the absence of fossils, the paucity of volcanogenic rocks, and the variable degrees of deformation or metamorphism affecting their fill units. However, this situation has changed significantly in recent years. Increasing use of the U-Pb SHRIMP and LA-ICPMS methods on detrital zircons is contributing to a better understanding of the timing and processes

\footnotetext{
* Corresponding author. Tel.: +55 6133071113.

E-mail address: faridchemale@gmail.com (F. Chemale).
}

involved in the generation and evolution of Archean and Proterozoic basins.

In the present paper, we report the results obtained in a detailed geochronological investigation using U-Pb SHRIMP and LA-ICPMS methods on zircons extracted from metasedimentary and metavolcanic rocks of the Espinhaço Supergroup, a Proterozoic quartzsandstone-dominated succession that is exposed along the homonymous mountain range in the State of Minas Gerais, eastern Brazil (Fig. 1A). The aim of this paper is to constrain the depositional ages of the Espinhaço Basin megasequences based on zircon dating of igneous and sedimentary rocks as well to understand the tectono-sedimentary evolution of the Espinhaço Basin in light of plate tectonic view during the Proterozoic.

\section{Geological setting}

The Espinhaço Supergroup comprises a package of metasandstones, metapelites and metaconglomerates with subordinate metavolcanic and carbonate rocks that is greater than $5000 \mathrm{~m}$ thick (Pflug, 1965; Dussin and Dussin, 1995; Uhlein et al., 1998; MartinsNeto, 2000 and Danderfer et al., 2009). The main area of occurrence 


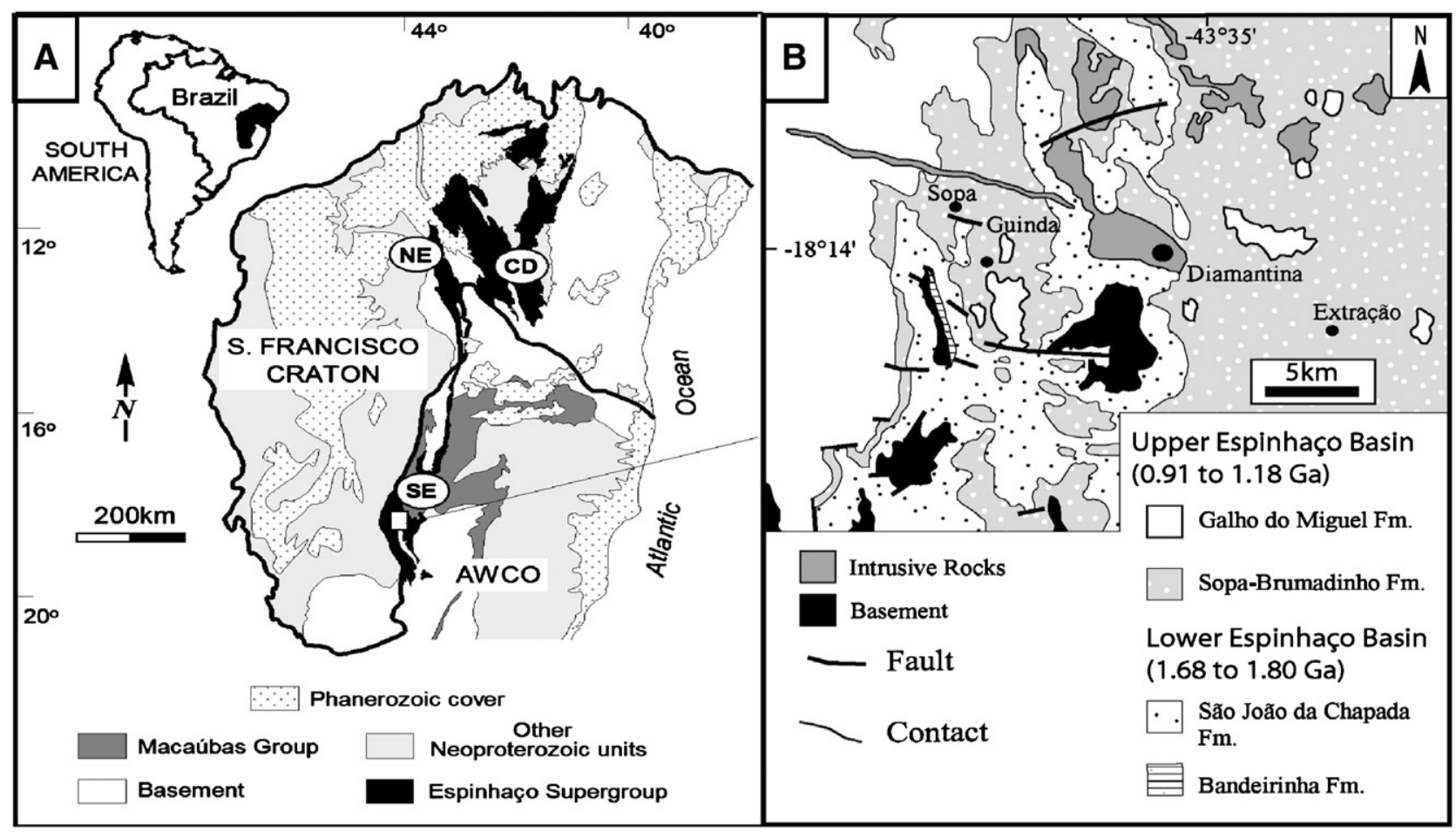

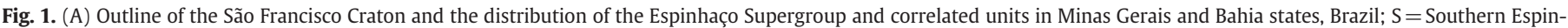

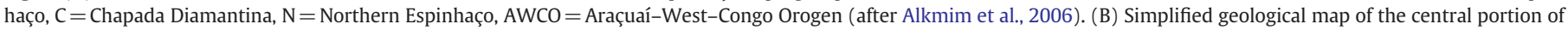
the Espinhaço Basin showing the locations of the studied areas Guinda-Sopa and Extração, (after Chaves, 1997).

of the Supergroup is the São Francisco craton and its margins in eastern Brazil (Fig. 1A). In this portion of the Brazilian shield, the Espinhaço Supergroup is exposed in the Chapada Diamantina, a large plateau located in the northern half of the craton, and in the Espinhaço mountain range, which is oriented roughly N-S and straddles over $1000 \mathrm{~km}$ in the craton's interior and along its eastern margin (Fig. 1A). Famous for its diamond-bearing conglomerates, the Espinhaço Supergroup is portrayed by many authors as the fill sequence of an intracontinental rift-sag basin system that developed around $1.7 \mathrm{Ga}$ in the continental mass that is presently represented by the São Francisco craton and its margins (Dussin and Dussin, 1995; Brito Neves et al., 1996; Uhlein et al., 1998; Martins-Neto, 2000). However, studies recently carried out in the craton's interior (northern Espinhaço range and Chapada Diamantina) (Fig. 1A) suggest a more complex development history for the Espinhaço basin, including at least a second rifting phase dated at ca. $1.57 \mathrm{Ga}$ (e.g., Danderfer et al., 2009).

The southern Espinhaço range is the morphological expression of the Neoproterozoic Araçuaí fold-thrust belt that fringes the São Francisco craton to the east and has been preserved during the Phanerozoic due the differential erosion of its dominant lithology (quartzite). The Araçuaí belt corresponds to the external domain of the Araçuaí-West Congo orogeny (640 to $490 \mathrm{Ma}$ ) that developed between the São Francisco and Congo cratons during the amalgamation of West Gondwana by the end of the Neoproterozoic (Alkmim et al., 2001, 2006 and Pedrosa-Soares et al., 2008). Affected by the folds and thrusts of the Neoproterozoic Brasiliano/PanAfrican orogen, the Espinhaço rocks that are exposed along the southern Espinhaço range exhibit conditions of metamorphic paragenesis of the lower greenschist facies (Dussin and Dussin, 1995; Uhlein et al., 1998). These metasedimentary rocks overlie an Archean/Paleoproterozoic basement, are cut by ca. $906 \pm 3$ Ma Ma mafic intrusives (Machado et al., 1989) and are unconformably overlain by the glaciogenic rifted margin succession of the Neoproterozoic (Tonian)
Macaúbas Group (Dussin and Dussin, 1995; Uhlein et al., 1998) (Figs. 1A and 2).

In the type locality, the Espinhaço Supergroup is subdivided into two groups and nine formations (Pflug, 1965; Dussin and Dussin, 1995) or (according to a sequence-stratigraphy approach) into six unconformity-bounded units (tectonosequences) (Martins-Neto, 2000) (Fig. 2). The two basal formations of the Espinhaço Supergroup are Banderinha and São João da Chapada Fm. and are separated by angular uncorformity (Fig. 2). These units are composed of alluvial sandstones, conglomerates and pelites and form a ca. 300-m-thick of two coarsening-upward sequences. K-rich alkaline volcanics and intrusives (Dussin and Dussin, 1995), locally known as hematite phyllite and comprised by sericite, hematite \pm chloritoide \pm quartz, intrude the Banderinha Fm. and the basal portion of São João da Chapada Formation. Zircons extracted from these K-rich alkaline volcanics by Machado et al. (1989) and Dussin and Dussin (1995) yielded $\mathrm{U}-\mathrm{Pb}$ ages of $1715 \pm 2 \mathrm{Ma}$ and $1710 \pm 12 \mathrm{Ma}$, respectively. The basal units of the Espinhaço Supergroup are herein interpreted as part of an intracontinental rift formed during the Statherian Period. Martins-Neto (2000) interpreted as records of the pre-rift and rift evolutionary stages of the Espinhaço basin (Fig. 2), which cannot be supported by the new geochronological data (see Discussion and conclusion section).

The Sopa-Brumadinho Fm. units overlie in angular unconformity the São João da Chapada lithologies as described by Santos et al. (unpublished data). The unconformity can be observed in the Serra da Miúda locality which separates different sandstones and also phyllites of the São João da Chapada Fm. from sandstones of the Sopa-Brumadinho Fm. The latter ones consist primarily of sandstones with plane-parallel stratification that pass vertically and laterally into pelites and diamonds- bearing conglomerates, which are well exposed in the Guinda and Sopa localities (Fig. 1A). In the locality of Extração, a 200 meter thick section of the Sopa-Brumadinho Fm. is exposed(Fig. 3), comprising from the bottom to the top,: (i) 


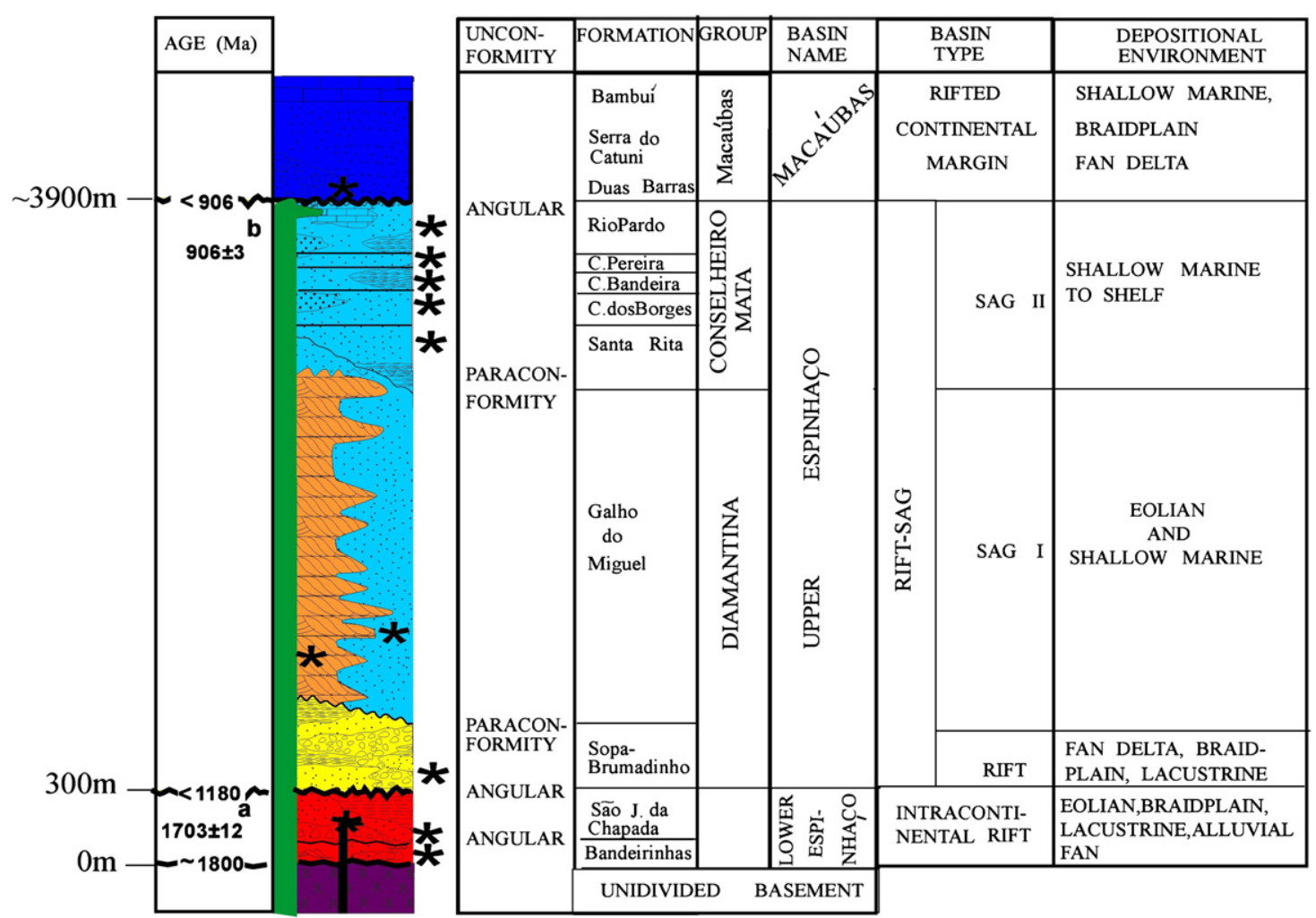

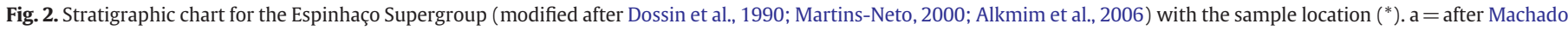
et al., $1989 ; \mathrm{b}=$ this work.

monomict conglomeratic quartzites with chanelled and tabular crossbending, (ii) diamond-bearing, basal polymict conglomerate with a greenish matrix of dacitic composition and pebbles of quartzite, ferruginous quartzite, banded iron formation and conglomerate, (iii). the intermediate section is composed by three main polymict conglomentrate levels and two layers of quartzite, where the matrix of conglomerate is quartz-rich and pebble of quartzite, white quartz, ferruginous and fuchsite-bearing quartzites, (iv) upper section of fine to medium grained feldspathic quartzite with channeled and tabular cross bedding. The sedimentation of the Sopa-Brumadinho Fm. formed and fan delta, braid-plain and lacustrine depositional environment.

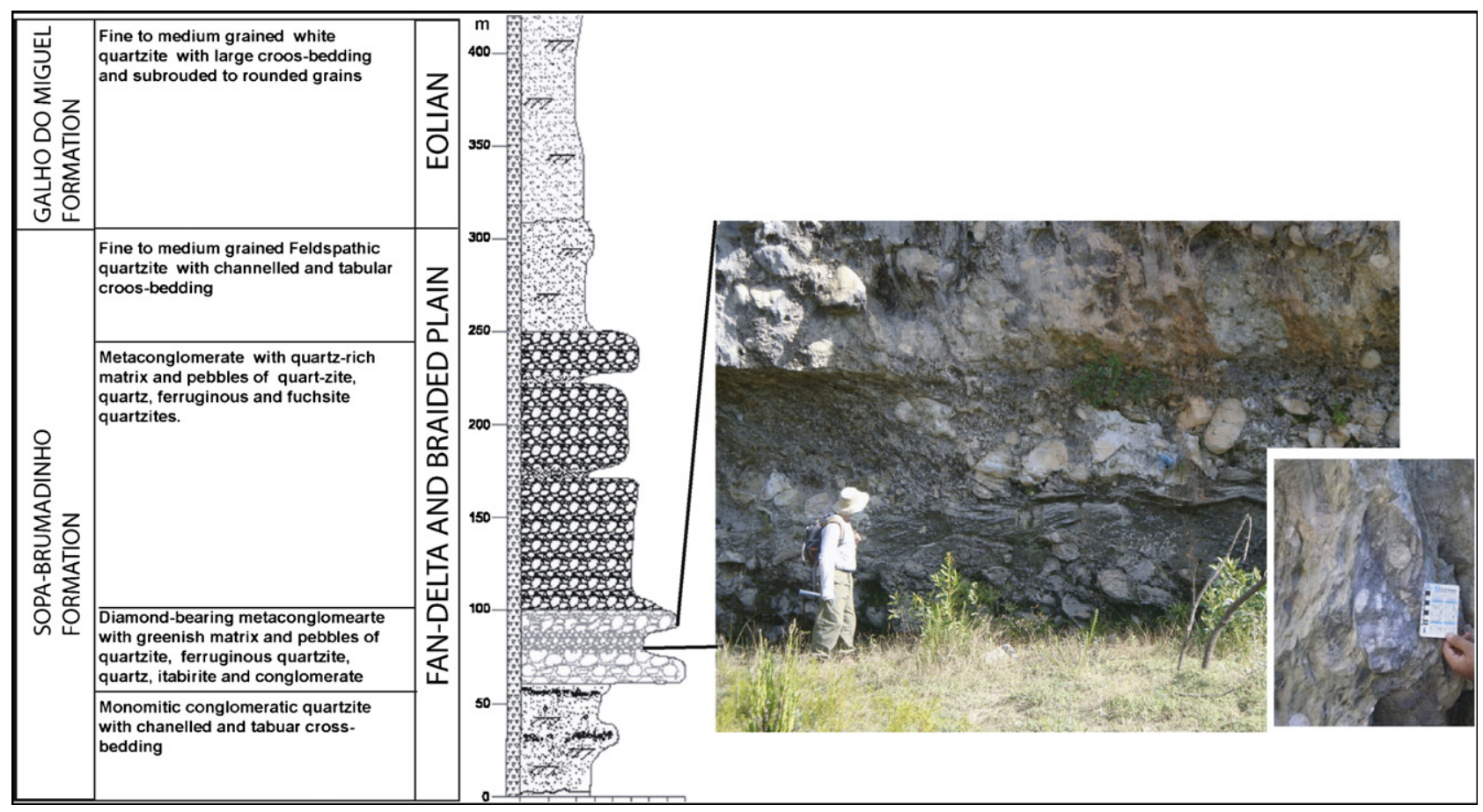

Fig. 3. Stratigraphic column of the Extraction Region (modified after Alvarenga, 1982). Detail of the meatconglomerate with greenisch matrix. 
Onlaping the basement highs and packages of the previously mentioned units, the Galho do Miguel Formation consists of a ca. 2500-mthick pile of aeolian and coastal quartz-arenites (Dussin and Dussin, 1995; Uhlein et al., 1998), which is interpreted as sag I sequence (Fig. 2). It shows a record of the first transgressive incursion and a substantial expansion of the Espinhaço basin and thereby marks the onset of the rift-sag transitional stage (Martins-Neto, 2000). The overlaying Conselheiro Mata Group, which is interpreted as sag sequence (Martins-Neto, 2000), comprises a ca. 900-m-thick marine succession of interbedded pelites and sandstones and contains lenses of carbonate rocks in the upper portion (Fig. 2).

\section{Analytical procedures}

Based on the quality of the outcrops and the large number of previous studies, we selected the type section of the Espinhaço Supergroup for our detailed geochronological investigation. This section is exposed in the central segment of the southern Espinhaço range near the town of Diamantina, Minas Gerais, in the localities of Guinda, Sopa and Extração (Fig. 1B).

For the purposes of our study, zircons were extracted from metasedimentary and metavolcanic rocks that are representative of all of the formations that are exposed in the southern Espinhaço range (Figs. 1 and 2). We also sampled the Duas Barras Formation, which comprises the basal quartz-sandstones of the Neoproterozoic Macaúbas Group that unconformably covers the Espinhaço Supergroup units of the Upper Espinhaço Basin in the study region. After heavy mineral separation, all zircons were mounted in circular epoxy 2.5$\mathrm{cm}$ in diameter and were polished until zircons were revealed. Zircons were photographed in transmitted and reflected light, imaged using BSE (backscattered electron) and CL (cathodluminescence), and dated using a laser ablation microprobe (New Wave UP213) coupled to a MC-ICP-MS (Neptune) at the isotope laboratories of universities of Brasília and Rio Grande do Sul (Brazil) and with a SHRIMP RG at the Research School of Earth Sciences, Canberra, Australia (ANU). The U-Pb analytical procedures and data are shown in tables of the electronic supplementary material (U-Pb Analytical Procedures, U-Pb SHRIMP_Data.xls, U-Pb LA-MC-ICMS_Data.xls, and Sample Coordinates.xls).

Data reduction used the SQUID software (Ludwig, 2001) for the SHRIMP data and excel sheet for the LA-MC-ICPMS data developed in the Isotope Laboratory of the UFRGS. The Concordia diagram and histograms were prepared with Isoplot/Ex (Ludwig, 2003). For detrital zircon histogram we use those zircons data with discordance equal or lesser then $10 \%$.

\section{Results}

The youngest ages that were obtained for the detrital zircons from the Bandeirinha and São João da Chapada Formations (the basal units of the Espinhaço Supergroup; Fig. 2), fall around 1704 to $1809 \mathrm{Ma}$. The Bandeirinha Fm. shows main peaks at $2089 \mathrm{Ma}, 2180 \mathrm{Ma}$, $2451 \mathrm{Ma}, 2711 \mathrm{Ma}, 3077 \mathrm{Ma}$ and $3271 \mathrm{Ma}$, whereas the São João da Chapada Fm. at $1711 \mathrm{Ma}, 2134,2701 \mathrm{Ma}, 3151 \mathrm{Ma}$ and $3336 \mathrm{Ma}$. (Fig. 4).

High-temperature magmatic zircons from a body of K-rich alkaline sill (hematite-phyllite) that intrudes into basal section of the São João da Chapada metasandstones near Guinda (Fig. 1B) yield a concordant age of $1703 \pm 12 \mathrm{Ma}$ (Fig. 5). This is the minimum age of the basal units of the São João da Chapada Formation, Espinhaço Supergroup, so that we estimated that the upper part of the São João da Chapada Fm. deposited at a maximum of ca.1.68 Ga. The Bandeirinhas and São João da Chapada are part of the Statherin intracontinental rift as represented as Lower Espinhaço Basin (LE) in the Figs. 2 and 6.
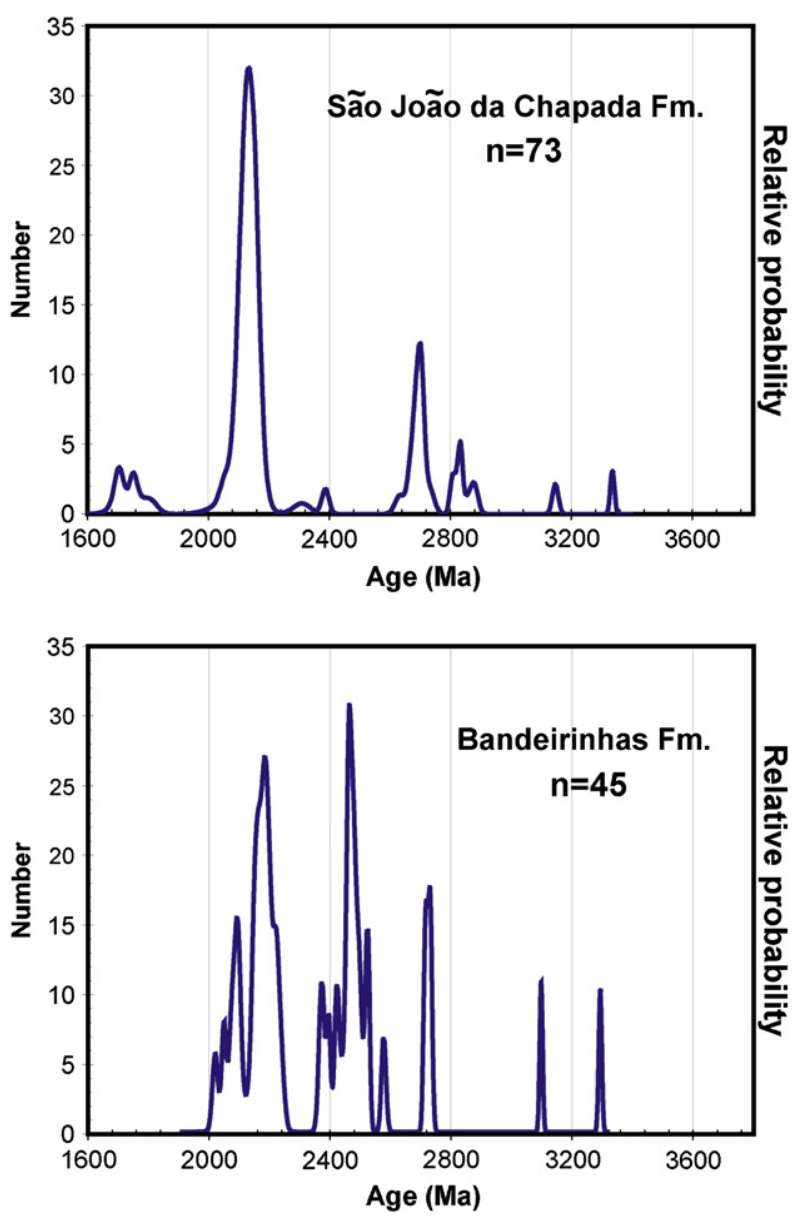

Fig. 4. Relative probability histograms for the detrital zircons from the basal units of the Espinhaço Supergroup.

Two samples from the diamond-bearing metaconglomerate of the Sopa Brumadinho Formation were collected in the Boa Vista Mine near the village of Extração (Fig. 1B); these are a greenish phyllitic matrix and a sandstone pebble (Fig. 3). The age spectra and zircon images obtained are shown in Fig. 7. Both samples have common age peaks as $2.722 \mathrm{Ma}, 2.139 \mathrm{Ma}$ and $1.748 \mathrm{Ma}$ for pebble sample and $2675 \mathrm{Ma}, 2142$ and $1795 \mathrm{Ma}$ for matrix sample, but ages that are

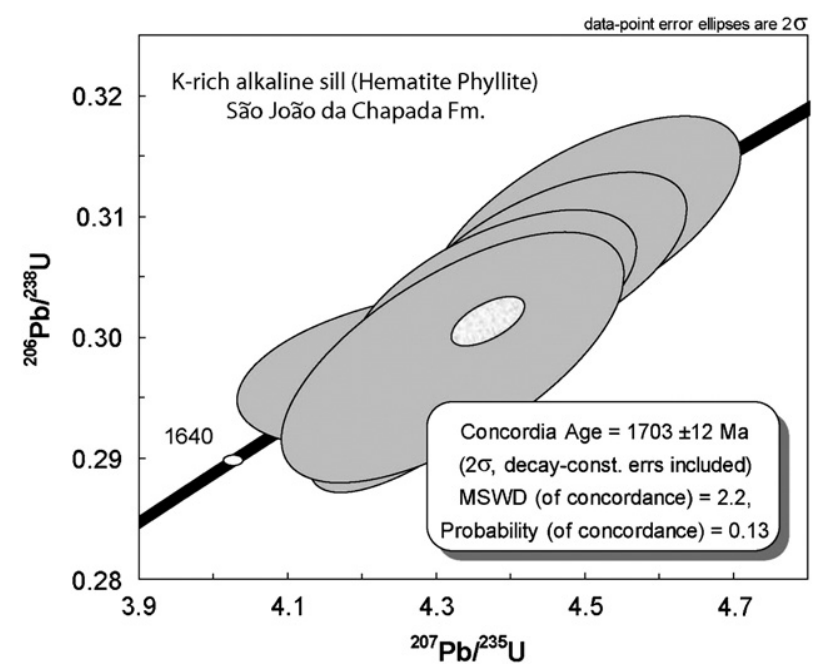

Fig. 5. Concordia diagram for the alkaline intrusion (Hematite Phyllite) in the basal section of the São João da Chapada Formation. 


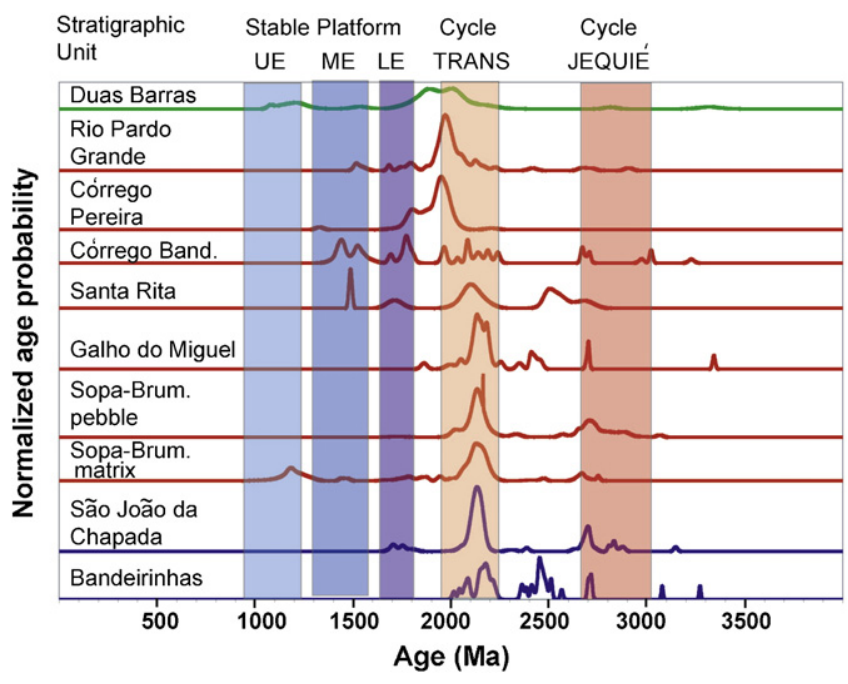

Fig. 6. Relative probability histograms for the studied samples from southern Espinhaço. The orogenic cycles are Jequié (Jequié) and Transamzonian (Trans). The three basins of the Espinhaço Supergroup in the São Francisco Craton and the adjacent Araçuaí Orogen are denoted as the Lower Espinhaço Basin (LE), the Middle Espinhaço Basin (ME) and the Upper Espinhaço Basin (UE).

approximately $2.1 \mathrm{Ga}$ (Rhyacian) are by far dominant. It is noteworthy that the youngest age group, which is obtained from zircons found in the matrix of the Sopa-Brumadinho conglomerate, falls within the interval between $1080 \pm 16$ and $1240 \pm 20 \mathrm{Ma}$ (with a peak at $1192 \mathrm{Ma}$; Fig. 7). Two other small peaks at 1341 and 1469 Ma can also be recognized in this sample. The youngest zircon population consists of magmatic zircons (volcanic origin) based in the alkali acid signature of the matrix and shape and inclusions of the zircons.

The samples collected in the Galho do Miguel Formation and the overlying units of the Conselheiro Mata Group yield age spectra that are similar to those of the Sopa-Brumadinho Formation (Fig. 6). However, the absence of ages younger than $1329 \mathrm{Ma}$ in all these samples
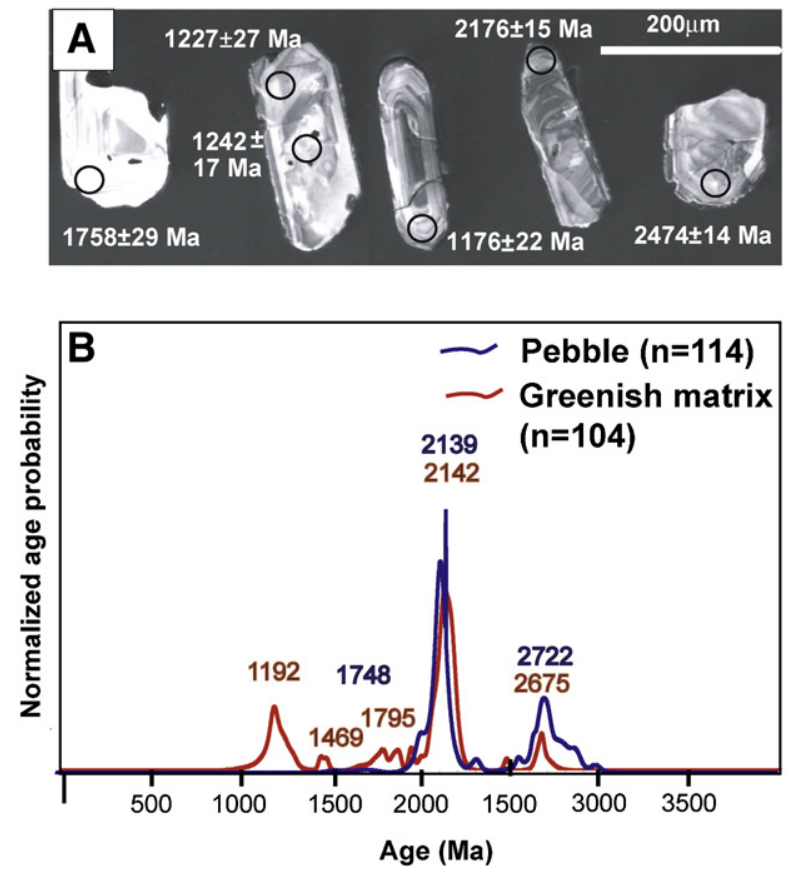

Fig. 7. A) CL-image of the $\sim 1.2 \mathrm{Ga}, 1.7 \mathrm{Ga}, 2.1 \mathrm{Ga}$ and $\sim 2.5 \mathrm{Ga}$ analyzed zircons of the greenish matrix of the diamond-bearing Sopa-Brumadinho metaconglomerate located at the Extração region. B) Relative probability histogram for the pebble and greenish matrix (with acid composition). is remarkable; that is, the peak of the Stenian ages documented in the Sopa-Brumadinho conglomerate is not reproduced by the samples from the overlying Espinhaço units. The youngest ages that have been obtained for the detrital zircons of the Galho do Miguel Formation are $1862 \pm 16 \mathrm{Ma}$, whereas the youngest detrital zircons from the Santa Rita, Córrego dos Borges, Córrego Pereira and Rio Pardo formations (Conselheiro Mata Group) are dated at $1487 \pm$ $40 \mathrm{Ma}, 1379 \pm 15 \mathrm{Ma}, 1329 \pm 12 \mathrm{Ma}$ and $1453 \pm 25 \mathrm{Ma}$, respectively. However, the main peaks in these marine sequences are dated at approximately 1.97 to $2.15 \mathrm{Ga}$. Archean ages of between $2531 \mathrm{Ma}$, $2705 \mathrm{Ma}, 3032 \mathrm{Ma}$ and $3348 \mathrm{Ma}$ occur as subordinate peaks (Fig. 6).

The ages of zircons extracted from the Duas Barras Formation, the basal unit of the Neoproterozoic Macaúbas Group, show peaks at around $1094 \mathrm{Ma}, 1219 \mathrm{Ma}, 1554 \mathrm{Ma}, 1901 \mathrm{Ma}$ and $2021 \mathrm{Ma}$ (Fig. 6). The youngest zircon is dated at $1079 \pm 16 \mathrm{Ma}$, but the maximum depositional age for the Macaúbas is younger than ca.910 Ma since this unit overlies the basic rocks dated at $906 \pm \mathrm{Ma}$ (Machado et al., 1989).

\section{Discussion and conclusions}

The new $\mathrm{U}-\mathrm{Pb}$ ages from the detrital and magmatic zircons presented in the previous section brings to light a new chapter in the history of the Espinhaço basin. The rift-sag sequence, represented by the Sopa-Brumadinho and overlying formations, accumulated between $1192 \mathrm{Ma}$ (age of youngest zircon peak) and $906 \mathrm{Ma}$ (age of mafic dykes cutting the Espinhaço package, Machado et al., 1989). In other words, the Sopa-Brumadinho and younger units, which represent approximately $85 \%$ of the total thickness of the Espinhaço Supergroup that is exposed outside of the São Francisco craton, were deposited during the course of the Stenian period or Stenian and Tonian periods (by the end of the Mesoproterozoic and the beginning of the Neoproterozoic Era). These rocks were not deposited immediately after 1.75 Ga as previously thought (e.g., Dussin and Dussin, 1995; Brito Neves et al., 1996). Only the basal units (the Bandeirinha and São João da Chapada formations) are representative of the basin initiation stage in the period (Statherian). Thus, the unconformity that is recognized at the base of the Sopa-Brumadinho comprises a ca. 500 Ma hiatus. Indeed, the detrital zircons that formed between 1.8 to $1.68 \mathrm{Ga}$ occur in the Lower Espinhaço Basin (LE in Fig. 6) and also in the fluvial and upper marine sections of Upper Espinhaço Basin as the SopaBrumadinho, Córrego Bandeira, Córrego Pereira and Rio Pardo Formations.

Our results also indicate that the only possible correlatives of the Sopa Brumadinho and younger formations in the craton's interior are the middle and upper portions of the São Marcos and Chapada Diamantina groups (as described by Danderfer, 2009), exposed in the state of Bahia (Fig. 1A). The 1.57 Ga rift-related magmatic event and younger ages that were documented for the Chapada Diamantina and northern Espinhaço ranges (e.g: Babinski et al., 1993; Danderfer et al., 2009) is missing in the studied section; however, it is represented in the Upper Espinhaço Basin units (see ME column in Fig. 6 and U-Pb zircon data), as the detrital zircon ages in Santa Rita, Córrego Bandeira, Córrego Pereira and Rio Pardo Grande formations. Indeed, zircon population of the ages bracking 1.4 to $1.6 \mathrm{Ga}$ were found in the Sopa-Brumadinho metaconglomerate and overlying units (Fig. 6). The provenance of these zircons would be from the Middle Espinhaço Basin units, which it is very well exposed in the Chapada Diamantina and Northern Espinhaço (Fig. 1A).

The obtained age spectra indicate that approximately 2.1-Ga-old Rhyacian rocks contribute to the majority of the southern Espinhaço basin zircons (Fig. 6). Whereas the 2.2-Ga to $1.9 \mathrm{Ga}$ old zircons of Lower Espinhaço Basin have been deposited direct from the basement rocks, in the Upper Espinhaço Basin (1.19 to $0.91 \mathrm{Ga}$ ) transport of crystalline basement and recycling of Lower Espinhaço Basin sediments and igneous rocks is observed in the analyses of collected quartzite pebble in the sample PE-EX-34 A (Table 2 of U-Pb La-MC- 
ICPMS.xls file on electronic supplement). Juvenile Rhyacian rocks form the basement of both the southern margin of the São Francisco craton and the crystalline core of the Neoproterozoic Araçuaí-West Congo orogen (Alkmim et al., 2006) (Fig. 1A). The basement of the NS-trending lobe of the São Francisco craton (located to the west of the southern Espinhaço range; Fig. $1 \mathrm{~A}$ ) is made up essentially of $\mathrm{Ar}$ chean rocks (Teixeira et al., 2000). Either it does not supply the Espinhaço basin with $2.1 \mathrm{Ga}$ old zircons or the eroded sequence was Paleoproterozoic. Thus, the depositional systems for both basins (the basal and upper Espinhaço basins) present dominant paleocurrents to the east (Alvarenga, 1982 and Martins-Neto, 2000), which could indicate a main sedimentary supply from the west.

An alternative is that the main source for the studied units lies to the east, corresponding to the region of the present-day Araçuaí-West Congo crystalline core and its continuation northward, as was proposed by Martins-Neto (2000). Archean zircons, which are well represented in the studied Galho do Miguel formation and in the older units, could have been shed from the craton to the west or east, as well as from the region to the southeast (the area presently occupied by the Guanhães basement block; Fig. 1). The Guanhães block is composed essentially of Archean gneisses that are intruded by large 1.73-Ga-old anorogenic plutons (Dussin and Dussin, 1995). The Statherian zircons that are found on both the Galho do Miguel and Sopa-Brumadinho formations could thus have been derived either from the Guanhães block or from the basal Espinhaço 1.701.73-Ga-old volcanics.

The origins of the Mesoproterozoic zircons are uncertain. As shown in Figs. 6 and 7, the youngest zircon population of the Espinhaço rocks was found in the matrix of the Sopa-Brumadinho conglomerate. The overlying units yield only older zircon populations, thereby recording a stratigraphic inversion of a non-orogenic source. Because of this, we suggest that anorogenic bodies, which were emplaced in the crust to the east of the southern Espinhaço basin at around 1.47, 1.34 and $1.19 \mathrm{Ga}$, were sources for the Mesoproterozoic zircons. The occurrence of such rocks in the craton's interior (which are not yet documented in the study regions of this paper) cannot be ruled out. Considering the fact that the 1.19-Ga-old zircons are found in the Espinhaço basin together with diamonds, characterizing their source would contribute to a solution for a long-standing question of the Espinhaço basin geology; that is, "what is the origin of the diamonds?'

Another important aspect of the Espinhaço Supergroup is that it corresponds to record of at least three basins, the Lower (1.68$1.80 \mathrm{Ga}$ ), Middle (1.4 to $1.6 \mathrm{Ga}$ ) and Upper Espinhaço Basin (0.91 to $1.19 \mathrm{Ga}$ ) (Fig. 6). All units have been deformed by thrust and fold deformation during Brasiliano in different degree of deformation (e.g.: Marshak and Alkmim, 1989 and Chemale et al., 1993). These units however have been deposited in an intraplate setting, between two main orogenic cycles of the Brazilian Shield, the Transamazonian and Brasiliano orogenic cycles. The process of agglutination and orogenic collapse of the Transmazonian Cycle occurred between 2.05 and $1.9 \mathrm{Ga}$, forming the Paleoplate São Francisco-Congo, where in stable conditions the sediments of the three basinal cycles deposited. The complete record of this three intraplate basinal cycles is very well preserved and exposed in the Chapada Diamantina region, because these units overly an Archean block, the Gavião Block (Barbosa and Sabaté, 2004) in the São Franscico Craton. On other side, in the Meridional Espinhaço are exposed only the Lower and Upper Espinhaço sequences, because this region may have formed a structural high from 1.6 to $1.4 \mathrm{Ga}$. The configuration of the Espinhaço units and chronological correlatives in the São Franscico-Congo Craton is similar to those of Phanerozoic basins in the Gondwana Supercontinent, as those units of the Paraná Basin (Milani and Ramos, 1998) or the Central Australian Basin (Shaw et al., 1991). The direct relation between higher sedimentation rate and thickening of sedimentary packages and global tectonics in these basins is well documented.
The higher sedimentation rate during the Permian-Carbonifeorus period of these intracratonic basins is result of major orogenic at border of Gondwana Supercontinent, when occurred the assembly of the Pangea.

It is also important that the units of the Upper Espinhaço Basin $(0.91$ to $1.19 \mathrm{Ga}$ ) may represent an extension of the passive margin sediments or foredeep basin that formed in an intraplate setting. As occurs in many intraplate basins, the increase in the sedimentary thickness of the marine section (the Conselheiro Mata Group, Fig. 2) and the corresponding unit to north of the Setentrional Espinhaço (the Cabloco Formation units in the Chapada Diamantina) can be associated with the Grenvillian tectonism at margin or inside of the São Francisco-Congo Craton.

Mesoproterozoic Kibaran Orogenic System of central Africa developed between 1.4 and $0.95 \mathrm{Ga}$ (from rifting to post collisional stage) situated in eastern part of the Congo Craton, with continental collision between 1250 and $1000 \mathrm{Ma}$ (Kokonyangi et al., 2006; Batumike et al., 2007), could thus contribute to the increase of sedimentary rate in the Upper Espinhaço Intracratonic Basin, similar as described for the intracratonic basins in the Gondwana during the Permian and Carboniferous periods (e.g. Shaw et al., 1991; Milani and Ramos, 1998). The youngest zircons (formed between 1080 to $1242 \mathrm{Ma}$ ) may record the collision process at the margins or inside of the Congo Craton which occurred during the amalgamation of the Rodinia Supercontinent.

In the Tocantins Province, the structural province between the São Francisco and Amazon Craton, bimodal-volcanism and layered-intrusive complexes (Ferreira Filho et al., 2010) formed between 1.3 and $1.25 \mathrm{Ga}$ (as early the rifting stage of the Central Goias Massif). The coeval intraplate magmatism of the Mesoproterozoic rifting may be also provide an alternative source for the significant number of zircons from the Sopa-Brumadinho Formation (formed between 1.3 and $1.25 \mathrm{Ga}$ ). Further studies are recommended to understand the meaning of the new geochronological data of the Espinhaço Supergroup and their relationship to the assembling of the Rodinia Supercontinent.

\section{Acknowledgements}

This research is part of the project 'Tectonic Evolution and Stratigraphy of Southern Espinhaço, Minas Gerais, Brazil' supported by the PETROBRAS. We thank Fabrício Vieira dos Santos and Barbara Alcântara Lima for analytical assistance. This manuscript benefited from the comments of J. O. Santos and anonymous reviewer.

\section{Appendix A. Supplementary data}

Supplementary data to this article can be found online at doi:10. 1016/j.gr.2011.08.016.

\section{References}

Alkmim, F.F., Marshak, S., Fonseca, M.A., 2001. Assembling West Gondwana in the Neoproterozoic: clues from the São Francisco craton region, Brazil. Geology 29, 319-322.

Alkmim, F.F., Marshak, S., Pedrosa-Soares, A.C., Peres, G.G., Cruz, S., Whittington, A., 2006. Kinematic evolution of the Araçuaí-West Congo orogen in Brazil and Africa: nutcracker tectonics during the Neoproterozoic assembly of Gondwana. Precambrian Research 149, 43-64.

Alvarenga, C.J.S., 1982. Comportanmento estratigráfico da formação Sopa-Brumadinho no distrito diamantífero de Extração (Diamantina). Congr. Bras. De Geologia, Salvador, Anais, 1, pp. 168-176.

Babinski, M. Van Schmus, W. R Chemale Jr, F, Brito Neves, B.B. Rocha, AJD., 1993. Idade isocrônica $\mathrm{Pb} / \mathrm{Pb}$ em rochas carbonáticas na Formação Cabloco, em Morro do Chapéu. Anais II Simp. do Craton São Francisco, SBG, Salvador, pp. 160-163.

Barbosa, J.S.F., Sabaté, P., 2004. Archean and Paleoproterozoic crust of the São Francisco Cráton, Bahia, Brazil: geodynamic features. Precambrian Research 133, 1-27.

Batumike, J.M., O'Reilly, S.Y., Griffina, W.L., Belousova, E.A., 2007. U-Pb and Hf-isotope analyses of zircon from the Kundelungu Kimberlites, D.R. Congo: implications for crustal evolution. Precambrian Research 156, 195-225. 
Brito Neves, B.B., Sá, J.M., Nilson, A.A., Botelho, N.F., 1996. A tafrogênese estateriana nos blocos paleoproterozóicos da América do Sul e processos subseqüentes. Geonomos $3,1-21$.

Chaves M.L. de S. C., 1997, Geologia e mineralogia do diamante da Serra do Espinhaço em Minas Gerais [Ph. D. Thesis]: São Paulo, IG/Uni São Paulo, 289 p.

Chemale Jr., F., Alkmim, F.F., Endo, I., 1993. Late Proterozoic Tectonism in the interior of the São Francisco Craton. In: Findlay, R.H., Banks, H.R., Veevers, J.J., Unrug, R. (Eds.), Gondwana 8: assembly, evolution and dispersal. Balkema, Rotterdam, pp. 29-41.

Danderfer, A., De Waele, B., Pedreira, A., Nalini, H.A., 2009. New geochronological constraints on the geological evolution of Espinhaço basin within the São Francisco craton - Brazil. Precambrian Research 170, 116-128.

Dossin, I.A., Dossin, T.M., Chaves, M.L.S.C., 1990. Compartimentação estratigráfica do Supergrupo Espinhaço em Minas Gerais - Os grupos Diamantina e Conselheiro Mata: Revista Bras. Geociências 20 (1-4), 178-186.

Dussin, I.A., Dussin, T.M., 1995. Supergrupo Espinhaço: Modelo de Evolução Geodinâmica. Geonomos 1, 19-26.

Ferreira Filho, C.F., Pimentel, M.M., Araujo, S.M., Laux, J.H., 2010. Layered intrusions and volcanic sequences in Central Brazil: Geological and geochronological constraints for Mesoproterozoic $(1.25 \mathrm{Ga})$ and Neoproterozoic $(0,79 \mathrm{Ga})$ igneous associations. Precambrian Research 101, 430-445.

Klein, G.D., 1995. Intracratonic basins. In: Busby, C.F., Ingersoll, R. (Eds.), Tectonics of Sedimentary Basins, pp. 459-478.

Kokonyangi, J.W., Kampunzu, A.B., Armstrong, R., Yoshida, M., Okudaira, T., Arima, M., Ngulube, D.A., 2006. The Mesoproterozoic Kibaride belt (Katanga SE D. R. Congo). Journal of African Earth Sciences 46, 1-35.

Ludwig, K.R., 2001. Squid 1.02: A User Manual: Berkeley Geochronological Center Special Publication, 2. 19 pp..

Ludwig, K.R., 2003. Using Isoplot/Ex, version 3.00, a geochronological toolkit for Microsoft Excel, Berkeley Geochronology Center Special Publication No. 1. 43 pp.

Marshak, S., Alkmim, F.F., 1989. Proterozoic contraction :extension tectonics of the southern São Francisco region, Minas Gerais, Brazil. Tectonics 8, 555-571.
Martins-Neto, M.A., 2000. Tectonics and sedimentation in a paleo/mesoproterozoic rift-sag basin (Espinhaço basin, southeastern Brazil). Precambrian Research 103, 147-173.

Machado, N., Schrank, A., Abreu, F.R., Knauer, L.G., Almeida-Abreu, P.A., 1989. Resultados preliminares da geocronologia U-Pb na Serra do Espinhaço Meridional: Boletim do Núcleo Minas Gerais. Sociedade Brasileira de Geologia 10, 171-174.

Milani, E.J., Ramos, A., 1998. Orogenias Paleozóicas no Domínio Sul-Ocidental do Gondwana e os Ciclos de Subsidência da Bacia do Paraná. Revista Brasileira de Geociências 28 (4), 473-484.

Pedrosa-Soares, A.C., Alkmim, F.F., Tack, L., Noce, C.M., Babinski, M., Silva, L.C., MartinsNeto, M., 2008. Similarities and differences between the Brazilian and African counterparts of the Neoproterozoic Araçuaí-West Congo Orogen. In: Pankhurst, J.R., Trouw, R.A.J., Brito Neves, B.B., De Wit, M.J. (Eds.), West Gondwana: PreCenozoic Correlations across the South Atlantic Region: Geological Society of London, Spec.Publ., 294, pp. 153-172.

Pflug, R., 1965. A Geologia da parte meridional da Serra do Espinhaço e zonas adjacentes. Rio de Janeiro, DNPM/DGM, Boletim, 266. 51pp.

Shaw, R., Etheridge, M., Lambeck, K., 1991. Development of the Late Proterozoic to MID-Paleozoic intracratonic Amadeus Basin in Central Australia: a key to understanding tectonic forces in plate interiors. Tectonics 10 (4), 688-721.

Sloss, L.L., 1963. Sequences in cratonic interior of North America. Geological Society of America Bulletin 74, 95-114.

Teixeira, W., Sabaté, P., Barbosa, J., Noce, C.M., Carneiro, M.A., 2000. Archean and Paleoproterzoic tectonic evolution of the São Francisco craton, Brazil. In: Cordani, U.G., Milani, E.J., Thomaz Fo, A., Campos, D.A. (Eds.), Tectonic Evolution of South América: Rio de Janeiro, 31st International Geological Congress, Rio de Janeiro, pp. 101-137.

Uhlein, A., Trompette, R.R., Egydio-Silva, M., 1998. Proterozoic rifting and closure, SE border of the São Francisco Craton, Brazil. Journal of South American Earth Sciences $11,191-203$. 